\title{
Commentary on "Congressional Informal Groups as Representative Responsiveness"
}

\section{Susan Webb Hammond, The American University}

"Congressional Informal Groups as Representative Responsiveness" by Arturo Vega focuses on an interesting topic - congressional caucuses - and examines an important theoretical concept - representation - using a new data set that he has gathered. In the contemporary era, congressional caucusesvoluntary groups of members of Congress, without formal recognition in chamber rules or line-item appropriations, that seek a role in the policy process - are increasingly salient congressional actors. ${ }^{1}$ The number of caucuses has increased dramatically during the 1980s; about 140 operated during the 102nd Congress (1991-1992). It is not surprising that caucuses have flourished during the 1970s and 1980s, two decades of structural decentralization during which members of Congress often pursued individual goals at the expense of collective action. I have argued elsewhere that caucuses, particularly in this environment, assist members in achieving individual goals and also help Congress achieve institutional goals (Hammond 1989). Vega's focus on caucuses is useful.

In focusing on representation Vega examines a major responsibility of members. By using the Eulau and Karps (1977) model of representation and responsiveness, and particularly by examining the components of responsiveness using his new data, Vega is able to extend understanding of congressional representation (see also Stevens, Mulhollan, and Rundquist 1981 on caucuses and representation). He gathers data to examine "representative roles and activities of caucuses." Although his focus is on the group, in examining caucuses and representation he implicitly links individual responsibility and group activity. I am sorry that this linkage is not made explicit, because such an analysis especially can contribute to an understanding of two levels that are linked by caucuses: that is, the roles of legislators-asindividuals and of the Congress as an institution. In a portion of his analysis he uses the typology of caucuses that my colleagues and I developed (see, e.g., Hammond, Mulhollan, and Stevens 1985), testing and confirming it-

SUSAN WEBB HAMmOND is Professor of Political Science in the School of Public Service at The American University, Washington, DC.

The American Review of Politics, Vol. 14, Autumn, 1993: 375-379

(C)1993 The American Review of Politics 
with one modification. This is the kind of building-on-previous-research that can be particularly useful. And, the data set is new, gathered through a mail survey of 100th Congress caucuses.

However, Vega promises more than he is able to deliver, primarily because the data presented do not analyze the theoretical concept of representation-as carried out by caucuses - as precisely as Vega claims. The fault, in my view, lies to a great degree in the research design. There are two elements to the problem. One is that the purpose of the survey is, in many ways, largely descriptive: in his introduction, Vega says that "Three questions focus the study: (1) what are the representative roles and activities of congressional groups? (2) are there differences in these roles and activities by group type? and, (3) are there patterns of group roles and activities that better explain congressional groups as extensions of representation?" The underlying theory regarding representation and responsiveness is stated. But the linkage between the theoretical and the empirical is not clearly established.

The second major and basic problem is with the data, and therefore with the analysis. There is overlap among the types of activities, the different roles, and between activities and roles. Tables 2, 3, and 4 display these overlaps. There is a level of hierarchy problem. For example, representation is a very broad role, and coalition-building, agenda-setting, and information (other listed roles) all can be subsumed under representation (the caucus may take an important information role because representation is a priority role). Further, representation is conceptualized as both a role and an activity (see Table 2), so that here, too, a similar problem of overlap exists. Wouldn't it be clearer to consider representation as, for example, a role, and to gather data on caucus activities that carry out that (representation) role? Finally, if the activities only are considered, there is a problem similar to that which results from the lack of clarity in the differentiation of roles: functions and activities are mixed, one action may carry out two activities, or an activity may be the action that carries out a higher order activity. For example, sponsoring legislation is not necessarily an activity that is distinct from representation. In fact, sponsoring legislation often is an activity that carries out a representation role, or is both an entrepreneurial and a representative activity, or is an activity that amounts to a subset of the representative activity. As with the role orientations, the activities are not distinct from each other. In short, if role variables also are activity variables, and if several apparently different roles also can be subsets of one of the roles, or if some activities are subsets of other activities, the research design is not adequately explicit and we cannot be confident that the data, or the findings, tell us what we say we are after. 
Although interesting, Vega's LSO/non-LSO analysis is, I would argue, a distinction without a difference, and may in fact be misleading because it does not reflect the real world of caucuses. Many of the larger caucuses with larger staffs and separate office space do have LSO status, but others do not. Each group - LSOs and non-LSOs-includes both structured and less-structured caucuses. Non-LSOs include the successful and influential Conservative Democratic Forum (the 'Boll Weevils') chaired by Rep. Stenholm (D-TX), the Aviation Forum, the Competitiveness Caucus, the Fire Service Caucus (423 members), and a number of much smaller groups. And, there are major variations within the LSO group. Having LSO status is about the only thing shared in common. Some "class of 19 " clubs, the Human Rights Caucus, the 34-member Populist Caucus, and the threemember Territorial Caucus all are LSOs without a central caucus staff housed in a caucus office. On the other hand, the Democratic Study Group, the Republican Study Committee, the Congressional Arts Caucus, and the Environmental and Energy Conference are LSOs with separate staffs and offices.

All LSOs provide information exchange, although the LSOs with a central staff and separate office tend to produce and provide a great deal more written information. The non-LSOs also are information exchange mechanisms, and some produce written materials. That they produce fewer written materials is an interesting descriptive finding that may not indicate any particularly important differences from LSOs. LSOs may place greater organizational emphasis upon the role of information, but only if information is defined as written reports, or explanations of bills on the whip notice - material that at least some of the LSOs regularly produce. If information is defined broadly - as, for example, the exchange of information in any form (through regular meetings of members or staff, among other things) - the findings would be different.

The findings seem to show that LSOs have more activities of a sort that require a larger, centralized staff (in an office) - which some LSOs have, and non-LSOs do not have. ${ }^{2}$ Caucuses with more staff should be expected to produce more information. Although LSOs are more structured (in the sense that they have a separate bank account and reporting requirements) and therefore may be more involved in all of the activities listed, I have not seen any data - either here or elsewhere - that supports the conclusion that LSOs and non-LSOs are qualitatively different if there is a representation issue of concern to a caucus. According to my own data, LSOs also are very concerned with agenda-setting, sponsor (and in fact develop) a great deal of legislation, and often are important actors in coalition-building, for example - as are non-LSOs. 
The identification of three caucus role/activity dimensions-Guardian, Mediator, and Service - is an interesting finding. In my view, the perspective that different types of roles indicate an emphasis on different components of responsiveness should be pursued further in future research. Vega may want to reformulate some variables to distinguish the dimensions more fully. As presented in this article, there is overlap between dimensions, and some differences relate more to locus or type of activity than to types of representation. For example, service groups may include service as a major part of their activities, but they also may work inside and outside the legislative institution. Guardians also can work inside and outside the legislative institution.

In summary, the article presents an interesting perspective and some interesting information. Although in my view the research design needs more precision and clarity, the approach, the data, and the effort to build on previous research are helpful. My comments evince the problems of theorybuilding and the crucial importance of defining categories and developing variables that truly are distinct from each other, and the care that must be taken to distinguish between higher- and lower-level variables, so that variables in a category are not subsets of another higher-order variable in that same category. I have dealt with many of these same issues in my own work on caucuses, and know how difficult it is. Although the specification of variables and implementation of the analysis may not be completely satisfactory, Vega has given us an interesting perspective and a useful framework for thinking about the group life of Congress, and specifically about caucuses and representation.

\section{NOTES}

\footnotetext{
${ }^{1}$ The definition is taken from the study of congressional caucuses by Hammond, Mulhollan, and Stevens (1985). See also our forthcoming and 1991 works.

${ }^{2}$ Most caucuses, whether LSO or non-LSO, have very small staffs - usually one, but sometimes as many as three or four. The Democratic Study Group, with a staff at times as large as 20, is the major exception. These numbers do not include the number of staff that caucuses can mobilize to assist on a caucus project: caucuses without central staff and office space identify a staff aide in each caucus member's congressional office who serves as a caucus link within that office.
}

\section{REFERENCES}

Eulau, Heinz and Paul Karps. 1977. The Puzzle of Representation: Specifying Components of Responsiveness. Legislative Studies Quarterly 2: 233-254. 
Hammond, Susan Webb. 1989. Congressional Caucuses in the Policy Process. In Lawrence Dodd and Bruce Oppenheimer, eds., Congress Reconsidered, 3rd ed. Washington, DC: Congressional Quarterly Press. 277-294.

1991. Congressional Caucuses and Party Leaders. Political Science Ouarterly 106: , Dar Agenda-Setting. Western Political Quarterly 38: 583-605.

Forthcoming. Informal Congressional Groups and National Policymaking.

Stevens, Arthur G., Jr., Daniel P. Mulhollan, and Paul S. Rundquist. 1981. U.S. Congressional Structure and Representation: The Role of Informal Groups. Legislative Studies Quarterly 6: 415-435. 
